\title{
Some observations on magnesium in cerebrospinal fluid
}

\author{
CHRISTOPHER PALLIS, IAIN MACINTYRE, AND HAROLD ANSTALL \\ From the Departments of Medicine and Chemical Pathology, Postgraduate Medical School, London
}

SYNOPSIS Investigation of 67 patients with neurological disorders (excluding meningitis) showed mean level of $\mathrm{Mg}$ in cerebrospinal fluid of $1.93 \pm 0.03 \mathrm{mEq}$./1. These figures are significantly loweroo than earlier figures published in the literature. Patients with polyradiculo-neuritis do not show the fall in cerebrospinal fluid $\mathrm{Mg}$ levels reported in cases of infective meningitis. The level of $\mathrm{Mg}$ in cerebrospinal fluid is maintained in the presence of low levels of plasma $\mathrm{Mg}$.

As pointed out elsewhere (MacIntyre, 1963; Alcock, MacIntyre, and Radde, 1965), our knowledge of the physiology of $\mathrm{Mg}$ has remained scanty because based until recently on laborious and rather imprecise methods of estimation. A rapid and accurate flame spectrophotometric method is now available (Alcock, MacIntyre, and Radde, 1960; MacIntyre, 1961), and we have therefore re-examined some basic data relating to $\mathbf{M g}$ in human cerebrospinal fluid and sought to extend them.

\section{PREVIOUS OBSERVATIONS}

Cohen (1927) first pointed out that $\mathrm{Mg}$ concentrations in human cerebrospinal fluid were on average 20 to $30 \%$ higher than in serum. This finding is even more remarkable when it is remembered that only some $70 \%$ of serum $\mathrm{Mg}$ is freely diffusible. Cohen's original observations were later confirmed by McCance and Watchorn $(1931,1934)$ and by Hunter and Smith (1960).

Examining the serum and cerebrospinal fluid of 18 hospital in-patients suffering from a variety of neurological disorders, other than meningitis, Cohen (1927) found the mean serum $\mathrm{Mg}$ level to be $2.11 \mathrm{mEq} . / .^{1}$ and the mean concentration in lumbar cerebrospinal fluid $2.70 \mathrm{mEq} . / 1$. McCance and Watchorn (1931), using the same technique, investigated 68 hospital in-patients (37 of them with parenchymatous neurosyphilis) and found mean values of $2.23 \mathrm{mEq} . / 1$. and $2.74 \mathrm{mEq} . / 1$. respectively. Hunter and Smith (1960), however, using a different microchemical method (Hunter, 1959) give figures nearly $20 \%$ lower. They found the mean concentra-

\footnotetext{
1 Values given in early papers (expressed in $\mathrm{mg}$. per $100 \mathrm{ml}$.) have been converted into $\mathrm{mEq}$./1. for comparison with more recent data. Received for publication 7 May 1965.
}

tion of serum $\mathrm{Mg}$ in 38 patients 'with mild non-o inflammatory neurological conditions' to be $1.61 \pm \frac{\mathbb{D}}{3}$ $0.11 \mathrm{mEq} . / 1$. and of cerebrospinal fluid $2.23 \pm 0$ $0.089 \mathrm{mEq}$. $/ \mathrm{l}$. It is clear that the normal range of $\mathrm{Mg}^{\mathrm{D}}$ concentration in human cerebrospinal fluid has notco yet been established beyond dispute. We have soughtor to obtain more data to this end.

Cohen (1927) also stressed the constancy of the cerebrospinal fluid level of $\mathrm{Mg}$. He showed that ite did not rise in response to an intramuscular injec-a tion of $\mathrm{MgSO}_{4}$ which significantly, although trans-D iently, raised the serum $\mathrm{Mg}$ level. McCance and Watchorn (1931) confirmed that the cerebrospinate fluid $\mathrm{Mg}$ did not rise when plasma levels were raised. The level in cerebrospinal fluid remained remarkably constant under these circumstances; in fact as the plasma $\mathrm{Mg}$ rose the cerebrospinal fluid values expressed as a percentage of plasma levels, fell fromo 134 to $89 \%$. Although these authors did not report any cases with low plasma $\mathrm{Mg}$ levels they concluded that 'the constancy of cerebrospinal fluid $\mathbf{M g}$ can be regarded as an established fact'. Evidence will beo presented that this is true, even in cases of tetany with very low plasma $\mathrm{Mg}$ levels.

Cohen (1927) finally mentioned that in three patients with meningitis the level of $\mathrm{Mg}$ in lumbaro cerebrospinal fluid was low, the values approxi- N mating those in plasma. Eisler (1928), on the other hand, stated that 'in infective meningitis the cerebro-0 spinal fluid $\mathrm{Mg}$ was so constantly raised as to be of diagnostic value'. McCance and Watchorn $\left(1931, \frac{\leftarrow}{\mathbb{\Phi}}\right.$ 1934) questioned Eisler's 'normal' readings and later $\stackrel{\odot}{+}$ confirmed Cohen's observations in relation to 0 meningitis. Hunter and Smith (1960) also confirmedō Cohen's data, showing that in tuberculous meningitis a definite gradient occurred between the concentra- $\overrightarrow{\mathbb{D}}$ tions of $\mathrm{Mg}$ in ventricular, cisternal, and lumbar 
fluids. These facts seem so well established that we have not sought to confirm them. We have demonstrated, however, that in polyradiculo-neuropathy (Guillain-Barré syndrome), a disorder still sometimes suspected of being of infective origin, this breakdown of the 'cerebrospinal fluid plasma barrier' does not occur.

\section{METHODS}

We have performed simultaneous estimations of $\mathrm{Ca}$ and $\mathrm{Mg}$ in both plasma and cerebrospinal fluid in 67 patients suffering from a variety of neurological disorders. Samples were obtained during diagnostic lumbar punctures or during myelography or air encephalography. At the same time blood was collected into heparin, the plasma being promptly separated. Concentrations of $\mathbf{M g}$ and $\mathbf{C a}$ were determined by flame spectrophotometry (MacIntyre, 1961).

\section{RESULTS AND DISCUSSION}

The results are recorded in Table I. Three points seem worthy of comment.

1 In 50 patients suffering from psychoneurosis, cerebrovascular disease, cerebral tumours, idiopathic epilepsy, degenerative neurological disorders, and degenerative disorders of the spine with neurological complications, the mean cerebrospinal fluid $\mathrm{Mg}$ was $1.88 \mathrm{mEq} . \pm 0.03 \mathrm{mEq} . / 1$. There were no significant differences between the clinical subgroups. We confirm Cohen's (1927) original observation that in such cases the concentration of $\mathrm{Mg}$ is higher in cerebrospinal fluid than in plasma, although our readings for both are substantially lower than those of early investigators. It has been shown that in the dog radioactive ${ }^{28} \mathrm{Mg}$ ions move rapidly and in both directions between plasma and cerebrospinal fluid (Oppelt, MacIntyre, and Rall, 1963). If the same applies to man the 'cerebrospinal fluid/plasma barrier' to $\mathrm{Mg}$ must be a functional, not a structural one.
2 Fifteen patients with polyradiculo-neuropathy (Guillain-Barré syndrome) were found to have a normal cerebrospinal fluid $\mathrm{Mg}$ (mean $2.09 \mathrm{mEq} . / 1$. $\pm \mathbf{0} \cdot 10$ ). Their spinal fluids did not differ significantly in this respect from those obtained in the various types of non-infective neurological disorder. Unlike what happens in infective meningitis, the gradient between cerebrospinal fluid and plasma $\mathbf{M g}$ is maintained in polyradiculo-neuropathy.

3 The concentration of $\mathrm{Mg}$ in cerebrospinal fluid may be maintained in the presence of a low plasma Mg. This has not been previously reported. Particularly interesting in this respect were our observations on two cases of infantile tetany.

\section{ILLUSTRATIVE CASES}

H.R. (H.H. 264653) A full-term female infant, born at home by normal delivery, was admitted eight days after birth. Forty-eight hours previously she had refused feeds and vomited. Later she had had three major seizures. Her general condition was good. The Moro response was excessively brisk and a positive Trousseau sign was noted. Serum Ca was $3.5 \mathrm{mEq}$./1., serum $\mathrm{Mg} 0.7 \mathrm{mEq}$./1.; cerebrospinal fluid Ca $2.1 \mathrm{mEq}$./1., cerebrospinal fluid $\mathrm{Mg} 1.8$ mEq./l. She improved on parathormone and vitamin D and did not relapse when these were discontinued.

K.B. (H.H. 265381) A female infant, the second of twins, was born in hospital by assisted breech delivery. On the eighth day twitching was noticed in the right arm, right leg, and right side of the face. She had several further attacks in the next 48 hours. She was very irritable and the Trousseau sign was positive. Serum Ca was $3.8 \mathrm{mN}$., serum $\mathrm{Mg} 1.2 \mathrm{mEq}$./1., later falling to $0.9 \mathrm{mEq} . / 1$; cerebrospinal fluid $\mathrm{Ca} 3.0 \mathrm{mEq} . / 1$., cerebrospinal fluid $\mathbf{M g} 2.2 \mathrm{mEq} . / 1$. She responded promptly to parathormone and did not relapse when this was discontinued.

These two cases provide further evidence that cerebrospinal fluid is not a plasma ultrafiltrate but is produced by mechanisms involving active transport.

TABLE I

SUMMARY OF RESULTS

\begin{tabular}{|c|c|c|c|c|c|}
\hline \multirow{2}{*}{ Diagnosis } & \multirow[t]{2}{*}{ Number of Cases } & \multicolumn{2}{|c|}{ Blood (mEq./l.) } & \multicolumn{2}{|c|}{ Cerebrospinal Fluid ( $m E q . / l)}$. \\
\hline & & $\mathrm{Ca}$ & $M g$ & $\mathrm{Ca}$ & $M g$ \\
\hline Psychoneurosis & 7 & $5.13 \pm 0.08$ & $1.69 \pm 0.06$ & $1.91 \pm 0.03$ & $1.79 \pm 0.03$ \\
\hline Cerebral arteriosclerosis & 5 & $5 \cdot 16 \pm 0.07$ & $1.66 \pm 0.07$ & $1.98 \pm 0.02$ & $1.90 \pm 0.05$ \\
\hline Cerebral tumours (primary) & 7 & $5 \cdot 17 \pm 0.03$ & $1.54 \pm 0.04$ & $1.87 \pm 0.03$ & $1.99 \pm 0.07$ \\
\hline Idiopathic epilepsy & 6 & $5.12 \pm 0.05$ & $1.74 \pm 0.06$ & $1.97 \pm 0.06$ & $1.77 \pm 0.13$ \\
\hline Disseminated sclerosis & 5 & $5.05 \pm 0.05$ & $1.68 \pm 0.10$ & $1.98 \pm 0.04$ & $1.90 \pm 0.05$ \\
\hline Motor neurone disease & 5 & $5.06 \pm 0.04$ & $1.60 \pm 0.08$ & $1.96 \pm 0.07$ & $1.94 \pm 0.07$ \\
\hline Syringomyelia & 2 & $5 \cdot 25$ & 1.65 & $2 \cdot 1$ & 1.85 \\
\hline Trigeminal neuralgia & 3 & 4.93 & 1.47 & $1 \cdot 87$ & $1 \cdot 80$ \\
\hline Spondylosis & 10 & $5 \cdot 12 \pm 0.06$ & $1.71 \pm 0.03$ & $2.03 \pm 0.06$ & $1.94 \pm 0.06$ \\
\hline $\begin{array}{l}\text { Polyradiculo-neuritis } \\
\text { (Guillain-Barré syndrome) }\end{array}$ & 15 & $5 \cdot 16 \pm 0.05$ & $1.67 \pm 0.05$ & $1.99 \pm 0.03$ & $2 \cdot 09 \pm 0.10$ \\
\hline Infantile tetany & $\begin{array}{l}\text { Case H.R. } \\
\text { Case K.B. }\end{array}$ & $\begin{array}{l}3 \cdot 5 \\
3 \cdot 8\end{array}$ & $\begin{array}{l}0.7 \\
1 \cdot 2 \\
\text { (later } 0.9 \text { ) }\end{array}$ & $\begin{array}{l}2 \cdot 1 \\
3 \cdot 0\end{array}$ & $\begin{array}{l}1 \cdot 8 \\
2 \cdot 2\end{array}$ \\
\hline
\end{tabular}


They illustrate a further point, namely, that even when seizures occur in magnesium-depleted patients, a low level of magnesium in the cerebrospinal fluid plays no part in their pathogenesis.

\section{REFERENCES}

Alcock, N., MacIntyre, I., and Radde, I. (1960). J. clin. Path., 13, 506. $\longrightarrow,-$, (1965). Nature (Lond.). In the press.
Cohen, H. (1927). Quart. J. Med., 20, 173.

Eisler, B. (1928). Z. ges. exp. Med., 61, 549.

Hunter, G. (1959). Analyst, 84, 24.

$\longrightarrow$, and Smith, H. V. (1960). Nature (Lond.), 186, 161. McCance, R. A., and Watchorn, E. (1931). Quart. J. Med., 24, 371 - (1934). Brain, 57, 333.

MacIntyre, I. (1961). Advanc. clin. Chem., 4, 1.

- (1963). J. chron. Dis., 16, 201.

Oppelt, W. W., MacIntyre, I., and Rall, D. P. (1963). Amer. J. Physiol., $205,959$. 